\title{
Advances and Perspectives in Research on Buffalo Milk Production and Mozzarella Cheese
}

\author{
Napolitano, Fabio $^{1}$; Mota-Rojas, Daniel $^{2}$; De Rosa, Giuseppe ${ }^{3}$; Álvarez-Macías, Adolfo Gpe. ${ }^{2}$; Braghieri, Ada ${ }^{1}$; \\ Bertoni Aldo $^{2}$; Flores, Karla ${ }^{2}$; Gómez, Jocelyn ${ }^{2}$; López, Gisela ${ }^{2}$; Guerrero-Legarreta, Isabel ${ }^{4}$; \\ Serrapica, Francesco ${ }^{3}$
}

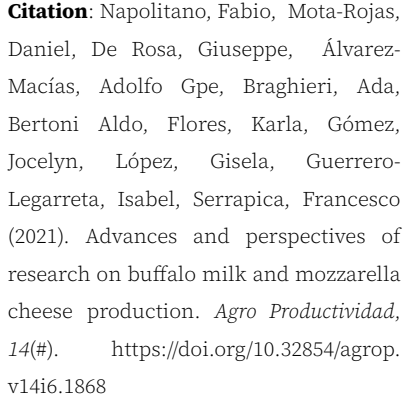

Editor in Chief: Dr. Jorge Cadena Iñiguez

Estimated publication date: July 2021

This work is licensed under a Creative Commons Attribution-NonCommercial 4.0 International license
${ }^{1}$ Università degli Studi della Basilicata. Scuola di Scienze Agrarie, Forestali, Alimentari ed Ambientali. Via dell'Ateneo Lucano 10, 85100 Potenza, Italia.

${ }^{2}$ Universidad Autónoma Metropolitana-Xochimilco. Departamento de Producción Agrícola y Animal. Calzada del Hueso 1100, Colonia Villa Quietud, Coyoacán 04960, Ciudad de México.

${ }^{3}$ Università degli Studi di Napoli Federico II. Dipartimento di Agraria. Via Università 100, 80055, Portici, Napoli, Italia.

${ }^{4}$ Universidad Autónoma Metropolitana-Iztapalapa. Departamento de Biotecnología. Av. San Rafael Atlixco 186, Iztapalapa, 09340 Ciudad de México.

* Corresponding author: aalvarez@correo.xoc.uam.mx

\begin{abstract}
Objective: To conduct a bibliographic review of the inventory and distribution of the buffalo herd, leading dairy buffalo breeds, and to map the main research topics for dairy buffaloes, emphasizing feeding methods and their effects on milk and mozzarella cheese quality.

Design/Methodology/Approach: Analysis of the main research topics on dairy buffalo, through a wide review of specialized journals.

Results: The production and processing of buffalo milk has gained relevance in recent years along different latitudes thanks to its nutritional qualities and the international regard for products such as mozzarella cheese. The main studies are carried out in Asia, Italy, and Brazil, emphasizing that diets are a determining factor in yield and quality of milk and its derivatives, but that genetics, environment, and animal management are what in the end model these characteristics.

Study Limitations/Implications: To conduct further research on dairy buffalo, especially in Mexico, where it has important development opportunities.

Findings/Conclusions: The bibliographic body of work presents practical restrictions, advances are recognized, and also the need to further research topics such as reproduction and animal welfare, management and valuation of buffalo milk and its derivatives, with the opportunity to explore organic production.
\end{abstract}

Keywords: Buffalo milk, mozzarella cheese, research, review.

\section{INTRODUCTION}

Milk as a research topic maintains a privileged position globally, given its relevance to the diet of millions of people and because it is one of the most complete sources of nutrition available. This attention has been focused on dairy cattle, which contributes $81 \%$ of global milk production. In recent years, however, buffalo milk has aroused great interest, as it contributes around 15\% of global production and, especially, due to its nutritional qualities that are superior to those of other mammals.

The relevance of the water buffalo can be seen in the notable growth of the global inventory, of 11\% between 2008 and 2018, with India and Pakistan standing out, where more than 70\% of the world's buffalo milk is produced (Khedkar et al., 2016). It is used in a range of dairy products, and due to its high nutritional value, is beneficial to the 
health of consumers (Napolitano et al., 2019). In Italy, it is processed into mozzarella cheese with a Protected Designation of Origin (PDO), and is highly valued internationally (Gulzar et al., 2019).

The properties and quality of buffalo milk and its derivatives are influenced by various factors such as the feeding regime and the health of the cows, environmental conditions and, in general, by the production system (Shelke et al., 2012; Bertoni et al., 2019a, b, c; De la Torre et al., 2019; Mota-Rojas et al., 2019a,b; Sabia et al., 2020). In response, a wide variety of studies have been carried out (Guerrero-Legarreta et al., 2019), thus this article sought to bring to light and discuss recent and relevant scientific findings on the dairy water buffalo cow and on mozzarella cheese, highlighting the main advances and topics that require further exploration. To this end, a vast bibliographic selection and review was carried out, prioritizing specialized journals.

\section{GLOBAL BUFFALO INVENTORY}

Statistics on the inventory of buffalos in the world are still not consolidated, but those by FAO (2018) provide a good start. In 2018, the buffalo population reached more than 206 million heads in the world, concentrated in Asia with 97.4\% of the total and an average annual growth rate (AAGR) of 1.01\% between 2008 and 2018, above the global average of $0.97 \%$ (Table 1 ). The three countries that stand out for their inventory in that continent are India, China, and Pakistan. Asia is followed by Africa, with $1.70 \%$ of the global inventory, with a negative AAGR of $1.4 \%$ in the same time span. In the Americas and Europe, a marginal part of this inventory has been accounted for, with 0.70 and $0.20 \%$, respectively, but with a relatively high AAGR of 1.75 and $2.55 \%$, respectively. The statistics for the Americas are scarce, but it has been estimated that the countries with the highest number of water buffalo are: Brazil with three million heads, Venezuela with 960 thousand, Argentina with 120,000, and in fourth place, Mexico with 45,000 (Patiño et al., 2016).

Table 1 shows the summary of the number of water buffalo heads in the world and by continent from 2008 to 2018.

Table 1. Number of buffaloes in the world, 2008-2018 (thousands of head).

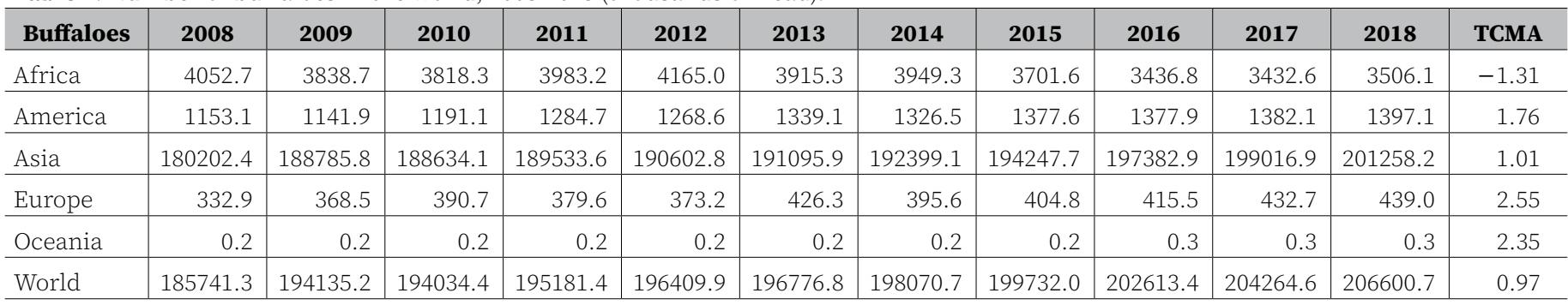

Source: FAO, 2018.

\section{The principal dairy breeds of water buffalo in the world}

The functional morphology of the cow is a key aspect for milk production which, according to the Italian National Buffalo Species Farmers' Association (ANASB), 
comprises a correctly aligned backbone, good rump development, a harmonious conformation of bone structure (body width and depth), adequate formation of hocks and hooves, as well as a developed mammary system. Of special importance is the adequate development of the hind quarters, where $60 \%$ of total milk is extracted (Zava and Sansinena, 2017).

Based on these characteristics, certain breeds have been prioritized depending on each context. In Asian countries, particularly in India, the Murrah, Nili-Ravi, Surti and Jaffabaradi breeds have been preferred and catalogued as the most productive after a long, non-systematic selection process. In particular, the global dominant breed, Indian Murrah, shows a milk yield of between 1,500 and 5,000 liters, depending on the ecosystem in which it develops, and frequently reaches an average butyric fat content of 7.5\% (Zava and Sansinena, 2017); females reach average weight of $550 \mathrm{~kg}$ and males exceed $600 \mathrm{~kg}$ (Almaguer, 2007). In Europe, the Mediterranean buffalo cows are preferred, and in lactation periods of 270 days, they register an average of 2,462 $\mathrm{kg}$, with $8.07 \%$ and $4.65 \%$ fat and protein content, respectively, with a high yield for products such as mozzarella cheese (AIA, 2018).

To illustrate the performance of certain buffalo breeds, Zhou et al. (2018) compared milk yields per day (Figure 1), as well as fat and protein content in the Murrah, NiliRavi, mixed, and Mediterranean breeds. This last one stood out with the highest yield and fat content (a little more than $8 \%$ ), although in protein it remained close to the average of the other breeds. In contrast, the Murrah breed showed the lowest yield, but a significant value in fat and protein.

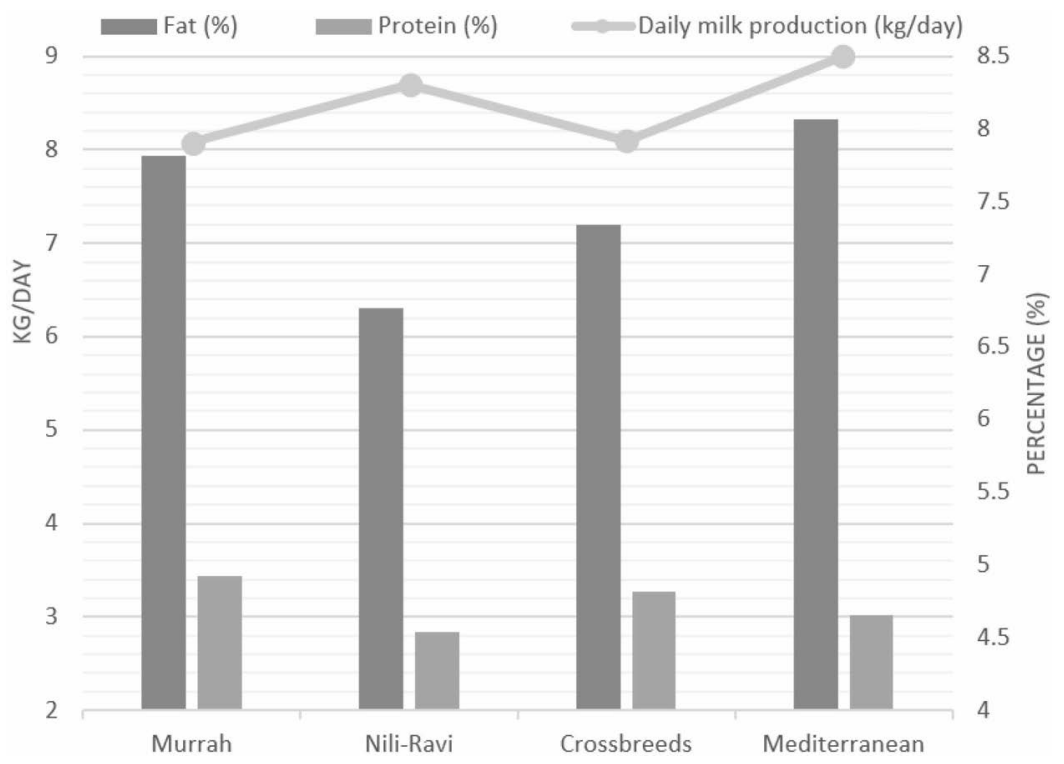

Figure 1. Daily milk production and percentage of fat and protein of four buffalo breeds. Source: Adapted from Zhou et al. (2018).

As to the breeds' characteristics, Murrah stands out with its jet-black color, soft and fine skin, curved horns, slight head and neck, short extremities, wide hips, and 
well-developed udder and teats, these being black, long, and robust (Mingala et al., 2017). The Nili-Ravi breed possesses similar characteristics to the Murrah, but is distinguished principally by the white marks present on its extremities, as well as the less-curled horns (Moioli and Borghese, 2005). The Jaffarabadi breed is characterized by wide horns that reach either side of its neck, a long body with a wide and deep chest, and an udder with very prominent veins and long teats (Mingala et al., 2017).

The European Mediterranean breed is characterized by long horns that point backwards and slightly outwards, a wide and deep chest, a wide but short rump, and a medium-sized udder with cylindrical teats (Borghese and Mazzi, 2005). In addition, the udder presents optimal traits for machine milking (Mingala et al., 2017). Concerning the Americas, both Brazil and Argentina have prioritized the Murrah, Mediterranean, and Jaffarabadi breeds, as well as crosses between them (Borghese and Mazzi, 2005).

Although the same breeds are used, milk yield during lactation varies substantially between different countries, as in the case of the Nili-Ravi breed, which in prior years reported a yield of 1,820 kg/cow/year in India, while in China it was 2,262 kg/cow/year (Borghese and Mazzi, 2005); this is due to the influence of the environment, and more generally, to the management of each production system.

\section{MAIN RESEARCHED TOPICS ON DAIRY BUFFALO COWS}

A great number of studies have been recorded that center on the dairy buffalo cow (Guerrero-Legarreta et al., 2019). They have focused on four main topics: health and reproductive aspects of the females, as well as quality of the milk and the mozzarella cheese. Figure 2 summarizes the most relevant scientific findings.

The following paragraphs delve further into the topics related to the production and quality of buffalo milk as well as the effects on mozzarella cheese quality, in order to form an initial assessment on advances and opportunities in this body of research.

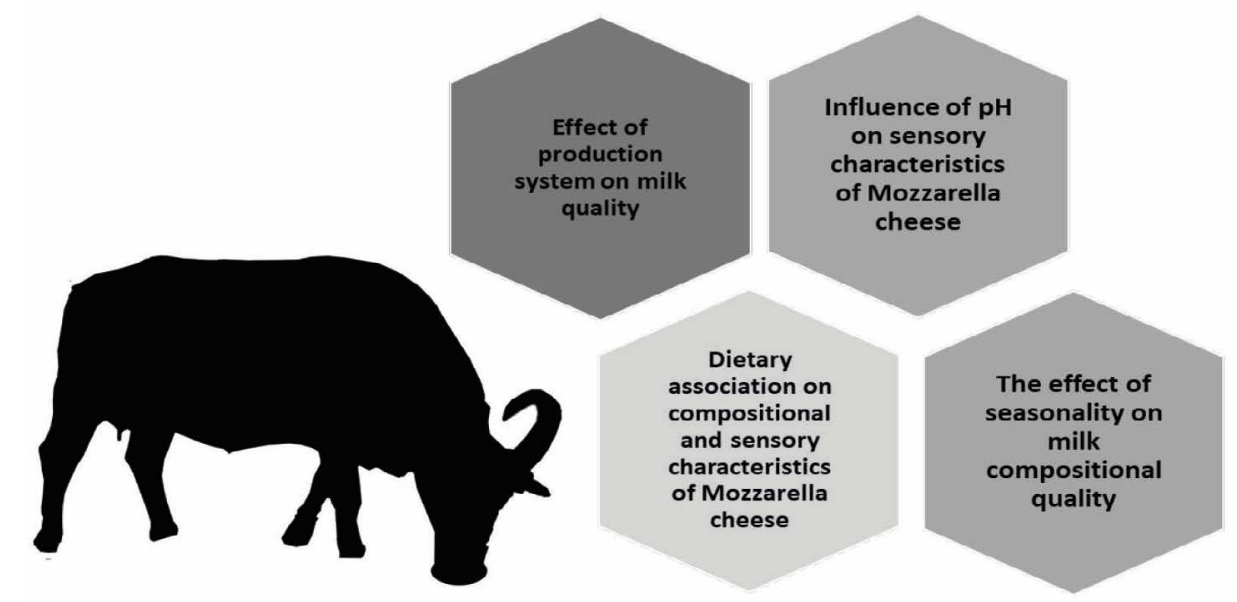

Figure 2. Themes and areas of knowledge recently identified in water buffaloes on milk and Mozzarella cheese quality. 


\section{Relation between production and quality of buffalo milk}

The diet of the buffalo cows has a special influence on milk quality; in India, Shelke et al. (2012) evaluated this among 19 Murrah buffaloes divided into two groups: the control group was fed maize forage, a mix of concentrate and wheat hay, while the treatment group was fed the same diet plus $25 \%$ fat and a concentrate supplement of mustard and peanut oil. The buffaloes were fed twice a day for 90 days and milk samples were collected during lactation to evaluate content of fat, protein, nonfat solids, and lactose using a milk caliber. The results revealed that the treatment group displayed greater milk production than the control group once the supplement was withdrawn, as well as a higher percentage of fat; in contrast, the percentage of protein, lactose, and non-fat solids were similar in both groups. This innovation is justified from the zootechnical perspective; however, its profitability would still need to be evaluated.

For their part, Patel et al. (2020) prepared pumpkin-flavored buffalo milk to define the sensory properties and storage characteristics, and to analyze its nutritional profile. They added pumpkin flesh and sugar in different proportions and conducted three evaluations: the sensory properties (taste, color and appearance) were evaluated by a panel; the nutritional analysis was carried out using chemical methods; microbial and nutritional characteristics were assessed on sterilized milk stored under ambient conditions for 180 days. The authors observed that the milk prepared with pumpkin flesh favors consumption due to its flavor and the sweetness from the added sugar, but increases the levels of carbohydrates and slightly decreases protein levels. Regarding storage, colonies of certain fungi were detected, induced by the conditions and ingredients with which the milk was processed.

In Brazil's Amazon region, the effects of two production systems (PS) on buffalo milk yield were studied (Barbosa et al., 2007). In PS1, pasture-fed animals were raised using Brachiaria humidicola and Pueraria phaseoloids, among others; during the dry season, they grazed on Pennisetum purpureum. The animals were given minerals ad libitum and were milked manually once a day. In PS2, the calves were separated at birth; cows were supplemented with a concentrated diet consisting of $60 \%$ maize and $40 \%$ rice bran, with one $\mathrm{kg}$ of concentrate per $3 \mathrm{~kg}$ of produced milk. The average milk yield of PS1 and PS2 was $3.2 \pm 1.29$ and $4.31 \pm 1.86 \mathrm{~kg} /$ day, respectively. For PS1, the most productive animals were from the 7/8 Murrah genetic group, while for PS2, it was those from the 3/4 Murrah group. The differences in milk production suggested a geneticenvironmental interaction in both production systems.

\section{Productive conditions for mozzarella cheese}

Most research on this subject has been recorded in Italy, given the large proportion of milk that is processed into this type of cheese (Pauciullo and Lannuzzi, 2017). Sabia et al. (2020) evaluated the effect of two diets, the first based on ryegrass hay and the second on ryegrass silage, on the volatile organic compounds of mozzarella cheese. The results showed that the compositional characteristics of the cheese, such as the 
cheese texture and aroma, varied depending on the diet. Cheese derived from buffalo cows fed with silage presented a higher percentage of fat, protein, and dry content. In terms of the cheese's texture, higher levels of viscosity and elasticity were detected in the mozzarella cheese from the buffalo cows fed with hay, which could be associated to a lower percentage of fat. Concerning the aromatic profile, it was found that terpenes such as linalool and aldehydes, as well as nonanal, were more abundant in cheese derived from animals fed with hay, both volatile components responsible for the citric aroma and characteristic taste of mozzarella. This coincides with the detection of a lower intensity of the herbaceous aroma of cheese derived from buffalo cows fed with hay. In addition, five compounds were identified that allowed for the distinction of cheeses based on the diet, which allows associating them with a specific geographic zone and confirming the identity of the cheese with respect to its Protected Designation of Origin label.

Other ingredients have also been administered in the buffalo cows' diets, such as in the case of Taticchi et al. (2017), who fed dried pitted olive marc (DPOM) to Mediterranean lactating buffaloes to measure yield and dietary-sensory characteristics of mozzarella cheese. The results revealed that there was no significant difference between the control group and the one that was administered DPOM in performance or body condition of the females, nor in the characteristics of the milk. However, the cheese produced from the milk of buffalo cows in the treatment group fed with DPOM showed a greater percentage of fat (26.1 vs 25.2\%), as well as a lower level of saturated fatty acids (77.7 vs $71.6 \%$ ), and a greater percentage of unsaturated and monounsaturated fatty acids (28.4 vs $22.3 \%$; 24.6 vs 18.8\%), which agrees with the lowest atherogenic and thrombogenic indexes (3.68 vs $4.95 ; 3.14$ vs 3.68). In the sensory evaluation, both groups had a positive score (white pearly color, smooth surface, good compaction, lactic aroma, soft texture, and sweet tase), demonstrating that the addition of DPOM did not cause negative effects on the sensory properties of the cheese and that it even improves it, since low atherogenic and thrombogenic indexes are correlated with a lower risk of coronary heart disease.

In another study, Uzun et al. (2018) analyzed the effect of including fresh fodder (sorghum) in the diet of lactating buffalo cows on the properties of mozzarella cheese. They did not find a difference in the profile of fatty acids in cheese produced from the milk of the control group compared to the group that was administered $10 \mathrm{~kg}$ of fresh sorghum; however, the cheese from the group that was administered $20 \mathrm{~kg}$ of fresh sorghum exhibited higher levels of mono and polyunsaturated fatty acids, low levels of saturated fatty acids, and a better atherogenic index score; in addition, this cheese was softer and moister. Therefore, this last diet reduced costs, improved the properties of mozzarella cheese, and favored acceptance from consumers.

Likewise, Ranucci et al. (2016) evaluated in Italy the seasonal effect (summer vs winter) on the composition and quality of mozzarella cheese from Mediterranean buffalo milk. They reported significant differences in the color: the cheese produced in the winter was darker and less yellow, which is attributed to the milk's higher water 
content. This quality influenced the sensorial evaluation, since consumers opted for these cheeses.

In Pakistan, Gulzar et al. (2019) studied the influence of the pH of milled curds, the effect of storage on quality (color, texture, and appearance), and the fatty acid profile of mozzarella cheese. They reported that whiteness decreased significantly as time in storage was prolonged, as did the $\mathrm{pH}$ of milled curds (5.2 to 4.9). Regarding texture, firmness decreased as $\mathrm{pH}$ went down, due to the dissociation of the casein micelle. In contrast, the authors reported that the $\mathrm{pH}$ of milled curds had a low influence on the fatty acid profile, while the time in storage had a significant influence, since the use of packaging with a weaker barrier against air and light could favor the oxidation of the cheese, which in turn could have a harmful effect on health, and therefore result in rejection from consumers.

\section{CONCLUSIONS}

Ever since the buffalo has come to be valued as a productive option globally, a more thorough inventory of animals in several countries has been achieved, corroborating that Asia is leading in both milk production and number of animals, while remarkable growth rates have been registered in the Americas and Europe. Likewise, dairy breeds are increasingly the object of planned selection processes.

The qualities of buffalo milk have been widely recognized for their high content in total solids and elevated cheese yield. Additionally, buffaloes have endured what are usually adverse climates for the majority of domesticated species, such as hot and humid conditions, in which buffaloes have shown an outstanding performance.

Regarding mozzarella cheese, more studies still need to be conducted to comprehend all the factors involved in its nutritional and bacteriological qualities. Specifically, changes in the diet and the use of natural additives tend to improve the nutritional levels and to favor a pleasant taste, and simultaneously, they can boost consumption among a wider public. Similarly, packaging that is effective for preserving characteristics such as softness and moistness and increase the shelf-life may promote the acquisition of larger markets.

This brief review showcased advances, but above all pointed to many areas that need to be addressed or at least expanded on, especially in countries like Mexico and its tropical regions, where there are high expectations for buffalo products. To this end, more must be explored, from the identification of good management practices, to aspects concerning milking and hygiene. In addition, further exploration is necessary regarding marketing tools to be used to increase milk production and dairy product yields, open new commercialization avenues and contribute to the development of local producers and marginal areas.

\section{REFERENCES}

IA. Associazione Italiana Allevatori. (2018). Controles Oficiales de productividad de la leche en Italia 2018. Consultado el 06 de septiembre de 2020. http://bollettino.aia.it/Contenuti.aspx?CD_GruppoStampe=TB\&CD_Specie=C4. 
Agro productividad 2021. https://doi.org/10.32854/agrop.v14i6.1868

Almaguer, P.Y. (2007). El búfalo, una opción de la ganadería. REDVET Revista Electrónica Veterinaria, 8(8), pp.1-23.

Barbosa, S.B.P., Pereira, R.G.A., Santoro, K.R., Batista, A.M.V., \& Neto, R. (2007). Milk yield of cross-bred buffalo under two production systems in the Amazonian region of Brazil. Italian Journal of Animal Science, 6 (2), 1071-1074. Doi: 10.4081/ ijas.2007.s2.1071

Bertoni, A., Álvarez-Macías, A., Mota-Rojas, D. (2019a). Capítulo 3. Desempeño productivo de los búfalos y sus opciones de desarrollo en las regiones tropicales. En: I. Guerrero-Legarreta, F. Napolitano, D. Mota-Rojas \& A. Orihuela (eds.), El búfalo de agua en las Américas, enfoques prácticos y experimentales (pp. 81-114). Segunda edición. Editorial BM Editores. México.

Bertoni, A., Mota-Rojas, D., Napolitano, F., Sabia, E., Álvarez-Macías, A., Braghieri, A., Mora, M.P., Di Francia, A., Morales, A., Berdugo, J., \& Guerrero-Legarreta, I. (2019b). Capítulo 4. Análisis comparativo entre búfalos de agua y ganado vacuno del género Bos: aspectos fisiológicos, anatómicos y productivos. En: I. Guerrero-Legarreta, F. Napolitano, D. Mota-Rojas \& A. Orihuela (eds.), El búfalo de agua en las Américas, enfoques prácticos y experimentales (pp. 115-153). Segunda edición. Editorial BM Editores. México.

Bertoni, A., Mota-Rojas, D., Napolitano, F., Berdugo, J., Crudeli, G., Pacelli, C., Álvarez-Macías, A., Morales, A., Gómez, J., Serrapica, F., José N., \& Orihuela, A. (2019c). Capítulo 14. Hallazgos reproductivos en el búfalo de agua mediante el uso de la termografía infrarroja. En: I. Guerrero-Legarreta, F. Napolitano, D. Mota-Rojas \& A. Orihuela (eds.), El búfalo de agua en las Américas, enfoques prácticos y experimentales (pp. 461-488). Segunda edición. Editorial BM Editores. México.

Borghese, A., \& Mazzi, M. (2005). Buffalo population and strategies in the world. En Buffalo production and research (pp. 1-39), FAO, Rome.

De la Torre, C.L., Guerrero-Legarreta, I., Napolitano, N., Serrapica, F., Cruz-Monterrosa, R.G., \& Mota-Rojas, D. (2019). Capítulo 24. Propiedades fisicoquímicas de la leche de búfala. En: I. Guerrero-Legarreta, F. Napolitano, D. Mota-Rojas \& A. Orihuela (eds.), El búfalo de agua en las Américas, enfoques prácticos y experimentales (pp. 812-835). Segunda edición. Editorial BM Editores. México.

FAO (2018). Food and Agriculture Organization of the United Nations Statistical Databases FAOSTAT. Consultado el 09 septiembre del 2020. http://www.fao.org/faostat/en/\#data/QA

Guerrero-Legarreta, I., Napolitano, F., Mota-Rojas, D., \& Orihuela A. (2019). El búfalo de agua en las Américas, enfoques prácticos y experimentales. Segunda edición. Editorial BM Editores. México.

Gulzar, N., Rafiq, S., Nadeem, M., Imran, M., Khalique, A., Sleem, I.M., \& Saleem, T. (2019). Influence of milling pH and storage on quality characteristics, mineral and fatty acid profile of buffalo Mozzarella cheese. Lipids in Health and Disease, 18(1), p.33. doi:10.1186/s12944-019-0976-9

Khedkar, C.D., Kalyankar, S.D., \& Deosarkar, S.S. (2016). Buffalo milk. In: B. Caballero, P.M. Finglas, F. Toldrá (eds.), Encyclopedia of Food and Health (pp. 522-528). UK.

Mingala, C.N., Villanueva, M.A., \& Cruz, L.C. (2017). River and swamp buffaloes: History, distribution and their characteristics. En G.A. Presicce (ed.), The buffalo (Bubalus bubalis)-Production and Research (pp. 3-31), Sharjah.

Moioli, B., \& Borghese, A. (2005). Buffalo breeds and management systems. Buffalo production and research. Rome: Food and Agriculture Organization of the United Nations, 51-76.

Mota-Rojas, D., De Rosa, G., Mora-Medina, P., Braghieri, A., Guerrero, L.I., \& Napolitano, F.(2019a). Dairy buffalo behaviour and welfare from calving to milking. CAB Review, 14(035). doi:10.1079/PAVSNNR201914035

Mota-Rojas, D., Orihuela, A., Napolitano, F., Serrapica, F., Olmos, A., Martínez-Burnes, J., Mora, M.P. \& De Rosa, G. (2019b). Capítulo 9. La búfala de agua durante el parto y ordeño: respuestas fisiológicas y conductuales. En: I. Guerrero-Legarreta, F. Napolitano, D. Mota-Rojas \& A. Orihuela (eds.), El búfalo de agua en las Américas, enfoques prácticos y experimentales (pp. 299-331). Segunda edición. Editorial BM Editores. México.

Napolitano, F., Mota-Rojas, D., Braghieri A., De Rosa, G., De Varona, E., Mora, P., Álvarez-Macías, A., Bertoni, A. \& Masucci, F. (2019). Capítulo 2. Comportamiento y bienestar de la búfala lechera. En: I. Guerrero-Legarreta, F. Napolitano, D. Mota-Ro- 
jas \& A. Orihuela (eds.), El búfalo de agua en las Américas, enfoques prácticos y experimentales (pp. 51-80). Segunda edición. Editorial BM Editores. México.

Patel, A.S., Bariya, A.R., Ghodasara, S.N., Chavda, J.A., \& Patil, S.S. (2020). Total carotene content and quality characteristics of pumpkin flavoured buffalo milk. Heliyon, 6(7).pp.1-5. doi: 10.1016/j.heliyon.2020.e04509

Patiño, E.M., Crudeli, G.A., Mitat-Valdés, A., (2016). Origen, Distribución y Razas. En G.A Crudeli, J.L. Konrad, E.M. Patiño, (Eds.), Reproducción en Búfalas (pp. 27-36). Moglia, Argentina.

Pauciullo, A., \& Iannuzzi, L. (2016). Molecular Genetics and Selection in Dairy Buffaloes: the Italian Situation, The Buffalo (Bubalus bubalis) - Production and Research, Presicce GA., Sharjah, pp. 50-68.

Ranucci, D., Garofalo, A., Urbani, E., Rea, S., Loschi, A.R., Stocchi, R. \& Branciari, R. (2016). Seasonal variations of Italian Mediterranean Buffalo (Bubalus bubalis) Mozzarella cheese quality. Journal of Dairy Research, 83(4), pp.476-478. Doi: 10.1017/ S0022029916000649

Sabia, E., Gauly, M., Napolitano, F., Cifuni, G.F., \& Claps, S. (2020). The effect of different dietary treatments on volatile organic compounds and aromatic characteristics of buffalo Mozzarella cheese. International Journal of Dairy Technology. 73 (7), pp.594-603. Doi: 10.1111/1471-0307.12696

Shelke, S.K., Thakur, S.S., \& Amrutkar, S.A. (2012). Effect of feeding protected fat and proteins on milk production, composition and nutrient utilization in Murrah buffaloes (Bubalus bubalis). Animal feed science and technology, 171(2-4), pp. 98-107. Doi: 10.1016/j.anifeedsci.2011.10.003

Taticchi, A., Bartocci, S., Servili, M., Di Giovanni, S., Pauselli, M., Mourvaki, E., \& Terramoccia, S. (2017). Effect on quanti-quality milk and mozzarella cheese characteristics with further increasing the level of dried stoned olive pomace in diet for lactating buffalo. Asian-Australasian Journal of Animal Sciences, 30(11), p.1605. doi:10.5713/ajas.16.0767

Uzun, P., Masucci, F., Serrapica, F., Napolitano, F., Braghieri, A., Romano, R., \& Di Francia, A. (2018). The inclusion of fresh forage in the lactating buffalo diet affects fatty acid and sensory profile of mozzarella cheese. Journal of Dairy Science, 101(8), pp.6752-6761. Doi: 10.3168/jds.2018-14710

Zava, M.A., Sansinena, M., (2017). Buffalo dairy production: A review. En: G.A. Presicce (ed.), The buffalo (Bubalus bubalis)-Production and Research (pp. 225-261), Sharjah.

Zhou, X., Qu, X., Zhao, S., Wang, J., Li, S., \& Zheng, N. (2017). Analysis of 22 elements in milk, feed, and water of dairy cow, goat, and buffalo from different regions of China. Biological trace element research, 176(1), pp.120-129. Doi: 10.1007/s12011-0160819-8 